\section{Nerrn denenerative \\ Diseases}

Anliker, B. 239

Barghorn, S. 197

Baumann, S. 290

Baumeister, R. 227

Beyreuther, K. 218

Braun, H.A. 290

Czirr, E. 298

Fahrenholz, F. 255

Griesshaber, B. 207

Haass, C. 193, 275, 284

Haffner, C. 284

Hartmann, T. 305

Jaeger, S. 233
Jeganathan, S. 197

Kaether, C. 275

Kins, S. 218

Larbig, G. 290

Lauther, N. 218

Li, X.-Y. 207

Lichtenthaler, S.F. 262

Mandelkow, E. 197

Mandelkow, E.-M. 197, 207

Matenia, D. 207

Müller, U. 239

Multhaup, G. 193, 270

Narlawar, R. 290
Pietrzik, C.U. 233

Postina, R. 255

Schmidt, B. 290

Smialowska, A. 227

St. George-Hyslop, P. 191

Steiner, H. 275

Szodorai, A. 218

Timm, T. 207

von Bergen, M. 197

Waldron, E. 233

Walter, J. 247

Weggen, S. 298

\title{
Subject Index Vol. 3, No. 4-5, 2006
}

Actin 207

ADAM10 255

Alzheimer's disease 197, 227, 233, 239 , 247, 262, 275, 290, 298

- - therapy 305

Amyloid $A \beta 270$

- precursor protein 233, 262, 270, 305

- precursor-like protein 239

Amyloid- $\beta 305$

- peptide 275, 298

$\beta$-Amyloid precursor protein 247

- $\quad$ - , in vivo function 239

Aspartic protease 290

Axonal transport 218

BACE inhibitors 290

Caenorhabditis elegans 227

Cargo receptor 218

Cholesterol 255, 305
c-Jun N-terminal kinase-interacting protein 218

Ectodomain shedding 262

Endocytosis 262

Endophilin 262

Functional redundancy 239

Glycosphingolipids 247

Homodimerization 270

Ibuprofen 298

Kinesin 218

Knockout mice 239

Low-density lipoprotein receptor-related protein 233

Microtubule-associated proteins 197

Microtubules 207

Modifier screen 227

Nicastrin-like protein 284

Nodal modulator 284

- signaling pathway 284
Nonsteroidal anti-inflammatory drugs 298

Oligomerization 270

p21-activated kinase 207

Paired helical filament 197

Phosphorylation of tau 207

Presenilin 227, 275, 284, 290

Retinoic acid 255

Secretase 290, 305

$\alpha$-Secretase 255

$\beta$-Secretase 270

$\gamma$-Secretase 275, 298

Secretases 262

Signal peptide peptidase 284

Sphingomyelin 305

Statins 305

Subcellular trafficking 247

Tau protein 197 